DOI: https://doi.org/10.4796o/2303-7431.25.2021.43

UDK: 821.163.42:398 Kukuljević Sakcinski I.:

Izvorni znanstveni članak

Primljen 6. V. 2021.

Prihvaćen 2. XI. 2021.

TANJA BARAN

Zagreb

baran.tanja@gmail.com

\title{
IVAN KUKULJEVIĆ SAKCINSKI KAO PRVI ZAPISIVAČ USMENE KNJIŽEVNOSTI U KRIŽEVAČKOME KRAJU
}

\section{Sažetak}

Ivan Kukuljević Sakcinski, osebujna i znamenita osoba iz vremena procvata hrvatskoga narodnog preporoda i nakon toga doba, u raznorodnome obilju svojega kulturnog i znanstvenog djelovanja, istaknuo se kao jedan od poticatelja zapisivanja usmene književnosti na cjelokupnome hrvatskom prostoru.

U radu se analizira zbirka usmenoknjiževnih pjesama koja je objavljena 1847. pod njegovim imenom, a u svezi je s križevačkim krajem, razlaže se problematika nastanka i identiteta te građe te se kontekstualizira $\mathrm{u}$ ondašnje društvene i političke prilike. Unatoč svim teškoćama u svezi s dokazivanjem postanka objavljenih pjesama, naglašava se iznimna važnost te zbirke jer je riječ o jednoj od prvih objavljenih cjelovitijih zbirki zapisa hrvatske usmene književnosti u cjelokupnome korpusu hrvatske književnosti. To je, uz vinsko-pajdaške regule Križevačke štatute, kojima se ne može sa sigurnošću odrediti točno vrijeme zapisa, ujedno i prva poznata objavljena usmenoknjiževna zbirka iz križevačkoga kraja pa 
se Ivan Kukuljević Sakcinski može nazvati prvim zapisivačem usmene književnosti u križevačkome kraju.

Ključne riječi: usmena književnost; 19. stoljeće; hrvatski narodni preporod; križevački kraj; županije i pukovnije

\section{Uvod}

Devetnaesto je stoljeće vrijeme naglašene težnje za upoznavanjem, otkrivanjem, zapisivanjem i analiziranjem cjelokupnoga hrvatskog identiteta, pa onda i kulturno-književnoga. Uz razne se društveno-političke prilike u Hrvatskoj i izvan hrvatskih granica stvorila atmosfera buđenja nacionalne svijesti, a onda i hrvatskoga narodnog preporoda koji je i u kasnijim razdobljima ubirao mnoge vrijedne i važne plodove. U tome se vremenu organizirano počela zapisivati usmena književnost, kao nikada dotada u Hrvatskoj. Poticaji su išli najprije od pojedinaca, a onda i od ustanova. Jedan od ključnih ljudi koji su upućivali obrazovane ljude diljem Hrvatske da zapisuju ne samo usmenu književnost nego i sve vezano za život, djelovanje, tradicije, baštinu i vjerovanja jest Ivan Kukuljević Sakcinski.

Tijekom 19. stoljeća zabilježeno je mnogo usmenoknjiževne građe na cjelokupnome hrvatskom prostoru. Niti križevački kraj nije ostao imun na poticaje pa je u tome vremenu prikupljeno petnaestak vrlo vrijednih usmenoknjiževnih rukopisa. ${ }^{1}$ Nešto je od prikupljenoga i objavljeno. Predmetna zbirka pjesama Ivana Kukuljevića Sakcinskoga najstarija je u korpusu poznate križevačke usmenoknjiževne građe pa se Sakcinskoga može smatrati prvim zapisivačem usmenoknjiževne građe u križevačkome kraju. Stariji od ove zbirke mogu biti samo zapisi najpoznatijih hrvatskih vinsko-pajdaških regula Križevačkih štatuta, koje je u prvoj polovici 19. stoljeća najvjerojatnije zapisao ugledni stenjevečki župnik

Vidi: TANJA BARAN, Usmenoknjiževno nasljeđe križevačkoga kraja u kontekstu hrvatske književnosti 19. stoljeća, doktorski rad, rukopis, Filozofski fakultet Sveučilišta u Zagrebu, Odsjek za kroatistiku, Zagreb, 2012. 
Tomaš Mikloušić, ali riječ je samo o pretpostavkama. Zato nema sigurnih dokaza. ${ }^{2}$

\section{Nacionalni usmenoknjiževni doprinosi Ivana Kukuljevića Sakcinskoga}

Ivan Kukuljević Sakcinski prvi je zapisivač križevačkih usmenih pjesama. Prvih dvanaest pjesama u kojima se spominje križevačko ime objavljeno je 1847. godine u iznimno važnoj zbirci Pěsme $s$ dodatkom narodnih pěsamah puka hàrvatskoga ${ }^{3}$ Ivana Kukuljevića Sakcinskog ${ }^{4}$.

2 Vidi: TANJA BARAn, Usmena književnost križevačkoga kraja: Križevački štatuti u hrvatskoj vinskoj kulturi i usmenoj književnosti, magistarski rad, rukopis, Filozofski fakultet Sveučilišta u Zagrebu, Odsjek za kroatistiku, Zagreb, 2003.

3 Ivan Kukuljević SaKcinski, Pěsme s dodatkom narodnih pěsamah puka hàrvatskoga (12 štokavskih $i$ kajkavskih pjesama iz križevačke regimenete, granice, varmeđe), knjiga četvarta, Tiskom kr. pov. ilir. n. tiskarne Dra Ljudevita Gaja, Zagreb, 1847.

4 Ivan Kukuljević Sakcinski, književnik i polihistor, kulturni i znanstveni radnik, političar (Varaždin, 1816. - Puhakovec, 1889.). Potomak je staroga hrvatskog plemićkog roda koji je, spojivši se s mletačkom lozom Bassani de Sacchi, dobio pridjevak Sakcinski. Školovao se u varaždinskoj franjevačkoj gimnaziji i zagrebačkome plemićkom konviktu gdje je započeo studirati filozofiju. Školu je napustio početkom 1833. pa je, odlučivši se za vojničko zvanje, postao kadetom 39. pukovnije u Kremsu u Austriji. Čitao je djela svjetskih romantičarskih književnika, sastavio je sedam njemačkih pjesama i davoriju An Kroatien koja je objavljena 1907. Godine 1835. napisao je svoju prvu izgubljenu hrvatsku pjesmu Pastir. Njemački prvopis junačke igre Juran i Sofija ili Turci kod Siska dovršio je 1836., a krajem te godine završio je i hrvatski prijevod te prve hrvatske drame ilirskoga razdoblja. Godine 1837. upoznao je Ljudevita Gaja koji ga je oduševio ilirskom idejom. Kukuljević je počeo surađivati u Danici u kojoj mu je odmah 1837. godine objavljena prva hrvatska pjesma Tuga za ljubom. Za vrijeme boravka u Beču 1840. godine pisao je pjesme i novele (Bugarin, Marta Posadnica, Pauk, Bratja) te niz djela na hrvatskome i njemačkome jeziku koja su djelomice sačuvana ili izgubljena. Prva knjiga Juran $i$ Sofija objavljena mu je 1839. u Zagrebu, a dramu mu je odmah izvela amaterska družina u Sisku. Godine 1840. njezinim zagrebačkim izvođenjem započelo je djelovanje novijega hrvatskog glumišta. Iste je godine Kukuljević bio premješten u Milano, gdje je za hrvatski jezik i književnost oduševio Petra Preradovića. Na vlastiti zahtjev 1842. napustio je vojnu službu i posvetio se kulturnopovijesnomu istraživanju i politici, uz desetogodišnju stanku u vremenu apsolutizma (1850. - 186o.). Bio je zastupnik u Hrvatskome saboru u kojem je 2. svibnja 1843. održao prvi govor na hrvatskome jeziku. Zatim je 1845. imenovan velikim sucem Varaždinske županije, blisko je 1848. surađivao s banom Josipom Jelačićem, od godine 1861. bio je veliki župan Zagrebačke županije. S Đurom Deželićem 1863. osnovao je Samostalnu narodnu stranku, banski je namjesnik bio od 1865. do 1867. Od 1851. do 1858. bio je predsjednik Matice ilirske, pa od 1874. do 1889. prvi predsjednik Matice hrvatske te počasni član JAZU (tek od 1886. jer je 1866. odbio imenovanje zbog neprimanja Ljudevita Gaja, Ivana Mažuranića, Dimitrija Demetra i Vjekoslava Babukića). Dopisivao se 
Riječ je o jednoj od prvih cjelovitijih zbirki zapisa hrvatske usmene književnosti koje je prikupio poznati hrvatski novelist, lirik, dramatik, putopisac, kritičar, biograf, historik, arheolog, publicist, bibliograf i skupljač starina, jedan od predvodnika hrvatskoga narodnog preporoda koji se istaknuo i kao političar te kao književni, umjetnički i politički povjesničar i znanstveni radnik u vremenu nakon preporoda.

Kako je odrastao i stasao u vremenu hrvatskoga narodnog preporoda, družeći se s ključnim ljudima koji su oblikovali društvenu i kulturnu stvarnost toga vremena, ne treba se čuditi Kukuljevićevu interesu za prikupljanjem narodnoga blaga. On usmenu književnost nije zapisivao prema poticajima neke institucije, nego ga je na to potaknulo ozračje vremena u kojem je živio. Na zapisivanje usmene književnosti poticao je i druge. Kao predsjednik Matice hrvatske prvi je darovao zbirku narodnih pjesama, „pjesme junačke i ženske, iz svih krajeva, naročito kajkavske ženske pjesme iz okoliša zagrebačkoga i Zagorja", nakon što je Matica 1877. godine uputila poziv na prikupljanje narodnih pjesama: „Prvi pokloni svoje ogromne zbirke predsjednik Ivan Kukuljević, što je sam sabrao i što je dobivao kroz dvadeset godina sa raznih strana kao predsjednik historičkoga društva. U ovom daru imade i krasna Tommaseova zbirka, koja imade osobito lijepih junačkih pjesama.“6

s europskim književnim, kulturnim i znanstvenim predvodnicima te bio član mnogih akademija. U svojim historiografskim i kulturnopovijesnim istraživanjima prikupio je građu bez koje se ne može zamisliti hrvatska pravna, politička i kulturna povijest, od dokumenata i isprava o hrvatskome državnom pravu, preko čitanja i vrednovanja Baščanske ploče, do bibliografije, enciklopedike i tekstova starih hrvatskih pisaca. Popis njegovih djela obuhvaća stotinjak naslova. Književni dio svojega opusa većim je dijelom objavio u četiri knjige $R a$ zličnih děla: dvije knjige Pripověsti (1842. i 1843.), Igrokazi (1844.) i Pěsme (1947.). Kukuljević je bio iznimno popularan sredinom 19. stoljeća, zatim je dugo bio osporavan i interpretiran gotovo isključivo kao istraživač starina i kulturni povjesničar, a manje kao književnik. Godine 1850. s kolegama je osnovao Društvo za povjesnicu jugoslavensku kojemu je bio predsjednik. Bio je i urednik Arkiva za povjesnicu jugoslavensku koji je marljivo uređivao gotovo četvrtinu stoljeća, od 1851. do 1875. godine. Usp. „Ivan Kukuljević Sakcinski“, Leksikon hrvatske književnosti, Vlaho Bogišıć i dr. (ur.), „Naprijed“, Zagreb, 1998., str. 187-189; Znameniti i zaslužni Hrvati od 925 - 1925, Odbor za izdanje knjige, Zagreb, 1925., str. 152 i 153.

5 Tade Smičiklas - Franjo Marković, Spomen knjiga Matice hrvatske 1842. -1892., Matica hrvatska, Zagreb, 1892., str. 54.

6 Isto, str. 53. i 54. 
Svoje ključne usmenoknjiževne doprinose Kukuljević je dao u Dodatku zbirkom pjesama iz 1847. godine te u objavi Pitanja Društva za jugoslavensku povjestnicu i starine, utemeljena 1850. godine, među kojima je bilo i pitanja posvećenih usmenoj književnosti, a zatim i objavljivanjem tih odgovora u Arkivu za povjestnicu jugoslavensku. Križevački usmenoknjiževni korpus zastupljen je u oba Kukuljevićeva prinosa. Križevačkih pjesama ima i u Dodatku zbirke pjesama, a odgovore iz Križevaca na Kukuljevićeva pitanja iz Križevaca poslao je mladić Milan Bubanović (Milan Dimitrev). Ti su odgovori i objavljeni u Arkivu 1857. godine. ${ }^{7}$ Od 26 pitanja odgovorio je na njih 12, na neka kratko, a na neka opširno. U korpus uglavnom povijesnih podataka o Križevcima i okolici mladi je zapisivač, prema Kukuljevićevim uputama, utkao i nekoliko usmenoknjiževnih žanrova. Zapisao je tri predaje, četiri vjerovanja i jednu izreku. ${ }^{8}$

Iz perspektive križevačkih usmenoknjiževnih zapisa zanimljivo je da je Kukuljević još kao četrnaestogodišnjak 1830. godine posjetio najvjerojatnijega prvog zapisivača najpoznatijih hrvatskih vinsko-pajdaških regula Križevačkih štatuta ${ }^{9}$, stenjevečkoga župnika Tomaša Mikloušića (Jastrebarsko, 1767. - Jastrebarsko, 1833.) koji je mladomu Sakcinskom preporučio čitanje hrvatskih knjiga. ${ }^{10}$

\section{Kukuljevićeva usmenoknjiževna zbirka}

U iznimno bogatome Kukuljevićevu stvaralačkom opusu Pěsme s dodatkom narodnih pěsamah puka hàrvatskoga zauzimaju posebno

\footnotetext{
7 Vidi: Milan Bubanović, „Odgovori na njekoja pitanja Družtva za jugoslavensku povjestnicu i starine: Od Milana Dimitreva“, Arkiv za povjestnicu jugoslavensku, br. 4, 1857., str. 191-199.

8 Vidi: TANJA Baran, „Vjerske teme usmenoknjiževnih zapisa Milana Bubanovića iz križevačkoga kraja“, Obnovljeni život: časopis za filozofiju i religijske znanosti, Zagreb, god. LXXIV. (2019.), br. 2., str. 207-216.

9 Vidi: Križevački štatuti.Vinsko-pajdaške regule za sve domaće, društvene prijateljske i pobratimske zabave $i$ veselice, sa 13 slika, sabrao i napisao kraj punog barila i lepepajdašice „Pajdaš Zvonko“ iz Vupoglave. [Dodatak: Koprivničke regule. - Varaždinski fureš. Krapinski vandrček. - Turopoljski štatuti. - Zagrebačka puntarija. - Ivanečka smešancija. - Svetojanskalumparija.] Tisak i naklada G. Neuberg, Križevci, 1918 - 1921.?

1o Usp. „Ivan Kukuljević Sakcinski“, $n$. dj., str. 187.
} 
mjesto. U predgovoru pjesničkoj zbirci, koja je objavljena uz potporu Ljudevita Gaja 1847. godine, Sakcinski je pokazao da mu je sasvim jasno kakvo je stanje zapisa hrvatskih usmenih pjesama. Žaljenje zbog rijetkih hrvatskih usmenoknjiževnih zapisa izrazio je već u prvome retku: „Cělomu učenomu světu poznate su narodne pěsmeslavjanske u svih narečjih, samo pěsme porekla hàrvatskogarědke su još polětele u bělisvět. Nitko se dosada nepobrinu sakupiti pěsmice pučke po zelenih livadah i po visokih gorah hàrvatskih. Nitko nepomisli na to, da pobere duhovno cvětje puka našega, pa da ga uplete $u$ věnac ostalih pěsamahslavjanskih." ${ }^{11}$ Sakcinski posebno žali zbog toga što su drugi slavenski narodi svoju usmenu književnu baštinu, za razliku od Hrvata, već dobrim dijelom prikupili te je predstavili europskoj kulturnoj javnosti:

Naš Vuk upozna sav svět s pěsmami puka našeg sàrbskog ili dolnjo ilirskog. Naš Simo razglasi junačka dělaCàrnogoracah s pěsmaminjihovimi. Naš Stanko priobćisvětu umiljati narodni duh naših gornjih Ilirah iz Koruške, Krajnske, Štajera i krajine ugàrske s popěvkaminjihovimi. Samo puk koj pod imenom hàrvatskim žive, kraj mora jadranskoga i tamo kraj rěkah Kupe, Save, Drave, Mure, Taje, Lajte i Morave, u dàržavihàrvatskoj, ugarskoj i austrianskoj, nije mogao sve do sada naći muža, kome bi bio povĕrio duhovno blago svoje. Pa ipak ima baš ovaj puk, stanujući u srĕdini naroda svoga ilirskoga, sjedinjena sva duševna svojstva ostale pojedine bratje svoje. ${ }^{12}$

Dalje u predgovoru spominje postojanje narodnih junačkih pjesama o senjskim uskocima, o junacima na granici, ali govori i o žalosno intoniranim pjesmama iz Austrije i Ugarske, što se ponekad ublaži, napisao je, ako se pjeva o ljubavi ili se žudi za slobodom. Sakcinski govori i o „provincijalnim” Hrvatima koji su uz povijesne pjesme sačuvali i pjevane uspomene iz poganskih vremena: „Tu se pěva od Lade i Lada od Hele i mlade nedělje, tu se slavi prolětje, koje ima svoje vile, komu se na žàrtvu loži kres, igra kolo, pletu věnci, pěvaju pěsme." ${ }^{13} \mathrm{Na}$ kraju predgovora otkrio je da je zbirku napisao kada je tumarao po svijetu, da je

I. Kukuljević SAKCinski, $n$. $d j$., str. 123.

12 Isto, str. $123-124$.

${ }_{13}$ Isto, str. 124. 
narodne pjesme slušao i prepisivao te da je zbirku mislio dati nekomu poput Sreznjevskoga ili Stanka Vraza da te zapisane pjesme uklopi u svoje veće zbirke. Međutim, to ipak nije učinio ističući da dobro poznaje hrvatske književne okolnosti po kojima je rijetko komu dopušteno objavljivati narodno blago. Sa željom da se objave pjesme na svim hrvatskim narječjima, Kukuljević je prikupljene pjesme i sâm grupirao u tri narječja: štokavsko, čakavsko i kajkavsko. Istaknuo je da je pjesme zabilježio onako kako ih puk izgovara i pjeva, zato što se, prema njegovu mišljenju, taj kriterij mora poštivati kada se zapisuju narodne pjesme. ${ }^{14}$

Na 256 stranica zbirke Kukuljević je objavio 12 pjesama uz koje je napisao križevačko ime te ih je grupirao u štokavske i kajkavske pjesme. Među štokavskim ima sedam, a među kajkavskim pet pjesama. Uz štokavske pjesme piše da potječu iz križevačke regimente (pet pjesama) ili križevačke granice (dvije pjesme), a uz kajkavske da je riječ o pjesmi iz Koprivnice u križevačkoj varmeđi (jedna pjesma), da je riječ o Bukovačkoj iz križevačke varmeđe, uz dvije piše da su Križevačke, a uz zadnju piše Oko Križevac.

\section{Problematika identiteta Kukuljevićeve križevačke usmenoknjiževne zbirke pjesama}

Već je prema određenju podrijetla pjesama jasno da će za većinu njih biti problem sa sigurnošću zaključiti da je riječ baš o pjesmama iz križevačkoga kraja u današnjem smislu, a posebice kada se pročitaju povijesni podatci o prostoru nekadašnje Križevačke pukovnije i Križevačke županije. Tu teškoću dodatno će pojačati sama analiza sadržaja i jezika pjesama. Regimenta je arhaičan naziv za pukovniju, vojnu postrojbu kopnene vojske. U Vojnoj krajini regimenta je bila teritorijalna jedinica ravna kotaru. ${ }^{15}$ Varmeđa (mađ. vármegye) naziv je za županiju, pokrajinu, upravnu oblast. ${ }^{16}$ Bogata je i duga povijest i Križevačke pukovnije, a posebice Križevačke županije.

14 Isto, str. $125-126$

15 Usp. Bratoluub Klaić, Rječnik stranih riječi, Nakladni zavod Matice hrvatske, Zagreb, 1990., str. 1143.

$16 \quad$ Isto, str. 1407. 
U povijesti stogodišnjeg hrvatsko-turskog rata (1493.-1593.) i Vojne krajine u nas, Križevačka županija može najslikovitije simbolizirati Hrvatsko Kraljevstvo od 16. stoljeća do druge polovice 19. stoljeća. Naime, kao što je cijela Kraljevina gotovo 300 godina bila podijeljena u civilni i vojni dio, tako je i nekad velika Križevačka županija sačuvala tek mali dio teritorija na kojem će hrvatski ban i Sabor imati vlast. Ostaci ostataka Križevačke županije obuhvaćali su samo one njezine dijelove na zapadu koji se naslanjahu na Varaždinsku i Zagrebačku županiju. Najmanje dvije trećine Križevačke županije pripale su Slavonskoj krajini, koja se sastojala od tri kapetanije: Koprivničke, Križevačke i Ivanićke. Po svom početnom zapovjednom sjedištu u Varaždinu bila je tijekom 16. i 17. stoljeća poznatija kao Vojna krajina Varaždinskoga generalata ili 'stara' Slavonska krajina. Stare kapetanije „stare“ Slavonske krajine nestaju u 18. stoljeću. Procesi krajiške modernizacije ukidaju kapetanijski ustroj i sredinom 18. stoljeća donose novu podjelu područja i stanovništva Krajine na pukovnije. Tako je stara slavonska krajina umjesto postojećih kapetanija dobila dvije pukovnije: Križevačku i Đurđevačku. (...) Križevačka pukovnija ulazi u 19. stoljeće s nekoliko već oblikovanih trgovačkih i obrtničkih središta. Uz dva vojna komuniteta djeluje i više manjih trgovišta sa svojim tjednim sajmovima u malim satnijskim naseljima. ${ }^{17}$

Iz spomenutoga je jasno kako su se granice Križevačke pukovnije tijekom prošlosti mijenjale, ali su bez obzira na vojne administrativne promjene uvijek bile šire od područja isključivo Križevaca i okolice.

Slično je bilo i s granicama slavne Križevačke županije koja je postojala još u srednjem vijeku. I Slavonija i Hrvatska dijelile su se na županije. Ferdo Šišić ističe da su stare plemenske župe nestajale jer su se sjedinjavale u županije po ugarskome kalupu, a županije nije više birao narod, nego ih je imenovao sam kralj po svojoj volji. Taj proces razvijao se u Slavoniji mnogo brže negoli u Hrvatskoj gdje su se stare hrvatske plemenske župe djelomično sačuvale sve do 14. stoljeća. U Slavoniji je prije dolaska Turaka bilo nekoliko županija, a najznatnija srednjovjekovna slavonska županija bila je Križevačka, također sastavljena od više manjih plemenskih župa (Čazmanska, Garićka, Garešnička, Grđevačka, Kalnička, Moslavačka i Rovišćanska), a prostirala se u 15. i u početku

${ }_{17}$ Mirko VAlentić, „Stara slavonska krajina i Križevačka pukovnija“, Križevačka pukovnija. Hrvatska na tajnim zemljovidima XVIII. i XIX. stoljeća, Biblioteka Hrvatska povjesnica posebna izdanja, Hrvatski institut za povijest, Zagreb, 2003., str. 41 i 57. 
16. stoljeća duboko u današnju Slavoniju, sve do Orahovice i Donjega Miholjca. Križevačka županija opkoljavala je sa zapadne, istočne i južne strane Virovitičku županiju, a u 15. i 16. stoljeću samo okoliš današnjega mjesta Virovitice do Drave. ${ }^{18}$

Križevačkoj je županiji susjedna bila Požeška županija. Cjelokupnu problematiku i mijene u Križevačkoj županiji tijekom prošlosti obrazložio je i Mirko Valentić ističući da je glavnina dostupnih podataka o Križevačkoj županiji iz vremena nakon 14. stoljeća:

U složenom društvenom i političkom procesu diobe kraljeve vlasti s plemstvom i stvaranja hrvatske plemićke zajednice nestale su brojne male županije. Samo na području Križevačke županije (od Drave do Save, zatim od Lonje na zapadu do Ilove na istoku) nestalo je više manjih županija: Garić, Moslavina, Gračenica, Česmica, Rovišće i druge. Sve one ušle su u sastav velike Križevačke županije koja je postala druga po veličini u Kraljevini Slavoniji. ${ }^{19}$

Da bi se ublažile mnoge nevolje preostaloga dijela Križevačke županije (koji nisu pokorili Turci), Hrvatski sabor donio je odluku da se civilni dio Križevačke županije ujedini sa Zagrebačkom županijom (1572.) i tako bar donekle zaštiti preostalo županijsko stanovništvo od čestog i raznovrsnog nasilja strane vojske (austrijskih plaćenika) i njezinih zapovjednika, jer vojska je svakodnevno bila nazočna u županijskim gradovima i drugim naseljima. Od tada je Zagrebačkom i Križevačkom županijom umjesto župana upravljao podban, kojega je, uz potvrdu Sabora, postavljao ban. Takvo će stanje potrajati sve do 1758., kad je ponovno uspostavljena samostalnost Križevačke županije sa središtem u Križevcima. ${ }^{20}$

Promjene granica Križevačke pukovnije i Križevačke županije događale su se i nakon objavljenih usmenoknjiževnih zapisa Ivana Kukuljevića Sakcinskoga ${ }^{21}$ Zato je uistinu teško znati na koje je područje Križevačke

${ }_{18}$ Usp. Ferdo ŠIšıć, Pregled povijesti hrvatskoga naroda, Matica hrvatska, Zagreb, 1916.; II. izdanje priredio JAROSLAV ŠIDAK 1962.; III. izdanje priredio TrPIMIR MACAN 1975.; izdanje Marjan tiska u dva dijela: 1. dio: od 60o. - 1526., 2. dio: od 1526. - 1918., priredio JAROSLAV ŠIDAK, Split, 2004., str. 258 i 259.

19 M. Valentić, „Pregled povijesti Križevačke županije“, Križevačka županija..., str. 41.

20 Isto, str. 44.

${ }^{21}$ „Ujedinjenje i oslobođenje od stoljećima duge austrijske vojničke vlasti proglašeno je u Bjelovaru 1. kolovoza 1871. bez velike svečanosti. Prvi izbori u Bjelovarskoj županiji za Hrvatski sabor provedeni su samo mjesec dana kasnije (5. rujna 1871.). Pobijedila je narodna stranka 
pukovnije ili županije Sakcinski mislio kada je napisao da su pjesme iz križevačke regimente, granice ili varmeđe. Nekako se može očekivati da je sredinom 19. stoljeća, kada je objavio zbirku, mislio na tadašnje administrativne granice, ali su i tada te granice bile puno šire nego što je to uistinu geografski određen križevački kraj. Osim toga, na prijelazu iz 18. u 19. stoljeće Križevačka je županija imala 68960 stanovnika. ${ }^{22} \mathrm{Ne}$ pomaže ni to što Sakcinski nije navodio imena kazivača pjesama. Još je u predgovoru naveo da pjesme dijeli u tri narječja: na štokavsko, čakavsko i kajkavsko, međutim, već pogled samo na prvu štokavsku pjesmu Dĕvojka budi dragog govori o tome da je zapravo riječ o kajkavskoj pjesmi. Nakon iščitavanja svih 12 Kukuljevićevih narodnih pjesama vezanih za Križevce nameće se zaključak da su sve kajkavske, pa čak i dvije epske deseteračke pjesme Iz križevačke granice, posvećene Marku Kraljeviću i netjaku Sekuli te Milošu harambaši. Po tome se može zaključiti da nijedna pjesma nije nastala u dijelovima nekadašnje Križevačke pukovnije ili županije u kojima se govorilo štokavskim narječjem.

Osim pjesama o Marku Kraljeviću i netjaku Sekuli te Milošu harambaši, ostale su pjesme lirske, različita su metra, a prevladavaju osmerci. Zanimljivo je kako svaka pjesma ima svoj naslov koji nije početni stih svake pojedine pjesme, kao što je to običaj u lirskim pjesmama. Svaki naslov pjesme završava točkom.

$\mathrm{Na}$ dnu stranice ispod prve pjesme (str. 127) Kukuljević je napisao: „Sliedeće su četiri pesme iz sbirke gosp. Dragutina Rakovca, koji ih iz granice prepisane dobi, ter iz prijateljstva meni odpusti. Druge ostale sve su po meni sabrane.“ To znači da su pjesme Dĕvojka budi dragog., Dragi i Draga., Tužna děvojka. i Děvojka prevari Boga., sve iz križevačke regimente, zapis Dragutina Rakovca. Moguće je da je sve četiri pjesme

na čelu s Ivanom Mažuranićem i osvojila svih 9 mandata. Povijesno područje Slavonske krajine zajedno s matičnim područjem Križevačke županije, koji nije dijelio sudbinu Vojne krajine, tvori sada novu Bjelovarsko-križevačku županiju sa sjedištem u Bjelovaru. U sklopu modernizacije javne (državne) uprave podijeljena je Bjelovarsko-križevačka županija (1875.) u tri podžupanije: Križevačku, Bjelovarsku i Koprivničku. Teritorij Križevačke pukovnije ostaje gotovo potpuno u Bjelovarskoj podžupaniji, a teritorij Đurđevačke pukovnije ostaje u Koprivničkoj podžupaniji.“ M. VALENTić, „Stara slavonska krajina i Križevačka pukovnija“, str. 62-63.

${ }_{22}$ Usp. M. VAlentić, „Pregled povijesti Križevačke županije“, Križevačka županija..., str. 50. 
Rakovcu kazivao isti kazivač jer su sve ljubavne te su jezikom i stilom dosta slične. Zadnju, petu pjesmu Iz križevačke regimente Sud neba nad zemljom Kukuljević je zabilježio sâm. Ispod nje napisao je: „Sravni ovu pesmu sa 'Svetci blago dijele' iz zbirke Vuka knjiga II. list I." Može se pretpostaviti da Kukuljević zbog sličnosti te i navedene pjesme koju je zabilježio Vuk Stefanović Karadžić upućuje na njihovo uspoređivanje. Riječ je o deseteračkoj raspravi između neba i zemlje uz zazivanje Božjega dara zdravlja i veselja na kraju pjesme.

Prva od dviju epskih pjesama, uz koje je napisano da su podrijetlom Iz križevačke granice, jest Marko Kraljević i netjak Sekula. Riječ je o opisu susreta i bitke dvojice junaka: Kraljevića Marka i mladoga Turčina za kojega se uspostavilo da je Kraljevićev nećak. Marko mu je na kraju svejedno odrubio glavu. Zanimljivo je da je inačica te pjesme pod nazivom Kraljević Marko i mlado Ture dijelom rukopisne zbirke I. M. Weissa. U toj zbirci piše da je pjesmu Kraljević Marko i mlado Ture Stjepanu Domi 1867. godine kazivao mladi slijepac imenom Karavljić iz Križevačke županije. Na kraju pjesme Stjepan Doma zapisao je: „Ova se pjesma doduše nalazi i u sbirci Filipovićevoj pod imenom 'Kraljević Marko i poturčeni nećak' (XLIV. str. 322), ali pošto je do sadržaja posvema drugačija, mislio, da mi se neće zamjeriti, ako i ovu popišem." Iz toga je jasno da je pjesma o Kraljeviću Marku i njegovu nećaku bila veoma popularna epska pjesma na širem prostoru pa zato i ima puno inačica. Sakcinski je svoju pjesmu objavio u zbirci 1847., a Stjepan Doma u Weissovu rukopisu 1867. godine. Starija inačica pjesme Iz križevačke granice zapisana je na kajkavštini, a mlađa $I z$ Križevačke županije na štokavštini. Time je zaokružen tzv. štokavski ciklus Kukuljevićevih narodnih pjesama za koje se veže podrijetlo iz križevačke regimente ili granice. Kajkavski je ciklus vezan za određenje varmeđom, dakle Križevačkom županijom, ili uz pjesme piše da su križevačke ili oko Križevca. Prva je iz toga ciklusa pjesma Sud nas grěšnom dušom. Uz nju piše da je Iz Koprivnice u križevačkoj varmeđi pa je jasno da je riječ o pjesmi koja je zabilježena u Koprivnici i ne pripada križevačkomu usmenoknjiževnom korpusu. Uz sljedeću pjesmu Ostavljeni ljubovnik. stoji da je Bukovačka iz križevačke varmeđe. Kao križevačke određene su tek pjesme Uspomena., koja je 
elegično sjećanje na majku i junake, te pjesma bez naslova, početnoga stiha: Kukavica Lado! zakukuvala, zapisana u ciklusu pjesama Kad Ladarice obilaze sela. Oko Križevac stoji uz stihove pjesme Na Ivanjski kres. koji su se pjevali uz godišnji običaj paljenja ivanjskih krijesova. Te zadnje tri pjesme koje su jedine jasno određene pripadnošću Križevcima i križevačkim krajem i svojim jezikom i sadržajem ponajprije vezanim za slavljenje pojedinoga običaja svjedoče da je Sakcinski bio u samim Križevcima i okolici te da je u križevačkome kraju zapisivao usmenoknjiževnu građu. Nije isključeno da je većina ostalih pjesama iz križevačke regimente ili granice također zapisana u tome kraju, ali to se ne može tvrditi sa sigurnošću.

\section{Zaključak}

Ivan Kukuljević Sakcinski ostat će zapamćen u križevačkoj i usmenoknjiževnoj povijesti kao prvi poznati zapisivač usmenih pjesama u križevačkome kraju. Tu činjenicu neće umanjiti ni to što je riječ o samo dvanaest zapisanih i objavljenih pjesama, od kojih je četiri zapisao Dragutin Rakovac, što je većina pjesama, osim zadnje tri koje su označene kao križevačke, određena križevačkom regimentom, granicom i varmeđom, te to što je sedam pjesama, iako su sve kajkavske, uvršteno među štokavske pjesme. Sakcinski je također svojim Pitanjima Društva za jugoslavensku povjesnicu i starine potaknuo mladoga Križevčanina Milana Bubanovića na zapisivanje i opisivanje križevačke povijesti, sakralnih spomenika, umjetnosti i usmenih predaja. Objavom njegovih odgovora u Arkivu za povjestnicu jugoslavensku 1857. godine Križevci su dobili prvi objavljeni zapis posvećen raznim aspektima svojih dragocjenih starina.

\section{Literatura}

- BARAn, TAnja, Usmena književnost križevačkoga kraja: Križevački štatuti u hrvatskoj vinskoj kulturi i usmenoj književnosti, 
magistarski rad, rukopis, Filozofski fakultet Sveučilišta u Zagrebu, Odsjek za kroatistiku, Zagreb, 2003.

- BARAn, TANJA, Usmenoknjiževno nasljeđe križevačkoga kraja u kontekstu hrvatske književnosti 19. stoljeća, doktorski rad, rukopis, Filozofski fakultet Sveučilišta u Zagrebu, Odsjek za kroatistiku, Zagreb, 2012.

- Baran, Tanja, „Vjerske teme usmenoknjiževnih zapisa Milana Bubanovića iz križevačkoga kraja“, Obnovljeni život: časopis za filozofiju i religijske znanosti, Zagreb, god. LXXIV. (2019.), br. 2., str. 207-216.

- Bubanović, Milan, „Odgovori na njekoja pitanja Družtva za jugoslavensku povjestnicu i starine: Od Milana Dimitreva“, Arkiv za povjestnicu jugoslavensku, br. 4, 1857., str. 191-199.

- „Ivan Kukuljević Sakcinski“, Leksikon hrvatske književnosti, VLAHO Bogišić i dr. (ur.), „Naprijed“, Zagreb, 1998., str. 187-189

- Klaić, Bratoljub, Rječnik stranih riječi, Nakladni zavod Matice hrvatske, Zagreb, 1990., str. 1407 i 1143.

- Križevački štatuti.Vinsko-pajdaške regule za sve domaće, društvene prijateljske i pobratimske zabave i veselice, sa 13 slika, sabrao i napisao kraj punog barila i lepepajdašice „Pajdaš Zvonko“ iz Vupoglave. [Dodatak: Koprivničke regule. - Varaždinski fureš. Krapinski vandrček. - Turopoljski štatuti. - Zagrebačka puntarija. - Ivanečka smešancija. - Svetojanskalumparija.] Tisak i naklada G. Neuberg, Križevci, 1918 - 1921.?

- Kukuljević Sakcinski, Ivan, Pěsme s dodatkom narodnih pěsamah puka hàrvatskoga(12 štokavskih i kajkavskih pjesama iz križevačke regimenete, granice, varmeđe), knjiga četvarta, Tiskom kr. pov. ilir. n. tiskarne Dra Ljudevita Gaja, Zagreb, 1847.

- Smičiklas, Tade - Marković, Franjo, Spomen knjiga Matice hrvatske 1842. - 1892., Matica hrvatska, Zagreb, 1892., str. 54.

- ŠIšić, Ferdo, Pregled povijesti hrvatskoga naroda, Matica hrvatska, Zagreb, 1916.; II. izdanje priredio ŠIDAK, JAROSLAV 1962.; III. 
izdanje priredio TRPIMIR MACAN 1975.; izdanje Marjan tiska u dva dijela: 1. dio: od 60o. - 1526., 2. dio: od 1526. - 1918., priredio JAROSLAV ŠIDAK, Split, 2004., str. 258 i 259.

- VAlentić, Mirko, „Stara slavonska krajina i Križevačka pukovnija“, Križevačka pukovnija. Hrvatska na tajnim zemljovidima XVIII. i XIX. stoljeća, Biblioteka Hrvatska povjesnica - posebna izdanja, Hrvatski institut za povijest, Zagreb, 2003.

- Valentić, Mirko, „Pregled povijesti Križevačke županije“, Križevačka županija. Hrvatska na tajnim zemljovidima XVIII. i XIX. stoljeća, Biblioteka Hrvatska povjesnica - posebna izdanja, Hrvatski institut za povijest, Zagreb, 2004.

- Znameniti i zaslužni Hrvati od 925 - 1925, Odbor za izdanje knjige, Zagreb, 1925., str. 152 i 153. 
Original scientific article

Received on May 6, 2021

Accepted on November 2, 2021

TANJA BARAN

\section{IVAN KUKULJEVIĆ SAKCINSKI AS THE FIRST RECORDER OF ORAL LITERATURE IN THE REGION OF KRIŽEVCI}

\section{Abstract}

Ivan Kukuljević Sakcinski, a distinctive and famous person from the flourishing period of the Croatian national revival and afterwards, in diverse abundance of his cultural and scientific work, distinguished himself as one of the promoters of recording oral literature in the entire Croatian territory.

The paper analyzes a collection of oral literary poems published in 1847 under his name and related to the region of Križevci. It explains the problems of origin and identity of those poems and contextualizes them into social and political circumstances of that period. Despite all the difficulties in providing the origin of published poems, the exceptional importance of this collection is emphasized because it is one of the first published complete collections of the Croatian oral literature records in the entire Croatian literature corpus. This is, along with the winedrinking brotherhoods' rules of the Križevci Statute, whose exact time of recording cannot be determined, the first known published oral literary collection from the region of Križevci, thus, Ivan Kukuljević Sakcinski can be called the first recorder of oral literature in the region of Križevci.

Keywords: oral literature; $19^{\text {th }}$ century; Croatian national revival; region of Križevci; counties and regiments 